\title{
Maximum size of Marbled spinefoot (Siganus rivulatus Forsskal \& Niebuhr, 1775) for Aegean Sea
}

\author{
Ozan Soykan ${ }^{1}$ (D), Anıl Gülşahin² (D), Hasan Cerim² (D)
}

Cite this article as: Soykan, O., Gülşahin, A. \& Cerim, H. (2021). Maximum size of marbled spinefoot (Siganus rivulatus Forsskal \& Niebuhr, 1775) for Aegean sea. Aquatic Sciences and Engineering, 36(1), 42-45.

ORCID IDs of the author: O.S. 0000-0002-2227-1245 A.G. 000-0001-8326-7672; H.C. $0000-0003-3025-1444$

${ }^{1}$ Ege University Faculty of Fisheries, Department of Fishing Technology and Seafood Processing Technology, Izmir, Turkey

${ }^{2}$ Muğla Sıtkı Koçman Umiversity Faculty of Fisheries, Department of Fishing Technology and Seafood Processing Technology, Muğla, Turkey

\section{Submitted:}

27.04 .2020

Revision Requested: 25.06.2020

Last Revision Received: 29.06.2020

\section{Accepted:}

09.07.2020

Online published:

03.12.2020

Correspondence:

Ozan Soykan

E-mail:

ozansoykan@hotmail.com

(C) Copyright 2021 The Author(s) Available online at

https://dergipark.org.tr/ase

\begin{abstract}
This study presents the maximum size record of Siganus rivulatus for the Aegean Sea with some additional biological information. The biggest individual of S. rivulatus was caught in Akbük Bight, Gökova Bay (Southern Aegean Sea) at 15 m depth with trammel nets on 29.01.2018. Specimenof marbled spinefoot was $27.1 \mathrm{~cm}$ in total length and $414.8 \mathrm{~g}$ in total weight. The specimen was female with a gonad weight of $2.43 \mathrm{~g}$ and it was determined to be 9 years old. The total length of the mentioned individual is the longest for Aegean Sea among the reported studies so far and weight measurement displays the maximum value not only for Turkey but also for European waters.
\end{abstract}

Keywords: Siganus rivulatus, marbled spinefoot, maximum size

\section{INTRODUCTION}

The marbled spinefoot (Siganus rivulatus Forsskal \& Niebuhr, 1775) is a marine and reef associated fish, which inhabits shallow waters on rocky or sandy bottoms down to $30 \mathrm{~m}$ depth (Froese \& Pauly, 2019). The S. rivulatus mostly occurs in the Western Indian Ocean, various localities in East Africa and from the Red Sea to the eastern Mediterranean. It was reported to be a Lessepsian migrant species (Ben-Tuvia, 1985) which invaded the Mediterranean and became one of the commercial alien fish for capture fishery (Saoud \& Ghanawi, 2010). Although it has a high commercial importance in the Mediterranean and Southern Aegan coasts of Turkey, scientific studies focusing on the biology (Yeldan \& Avşar, 2000; Bilecenoğlu \& Kaya, 2002; Ergenler, 2016) and the fisheries of the species are limited.

Maximum length and weight (MLW) are useful and important parameters in fisheries management (Dulčić \& Soldo, 2005). Information obtained from MLW measurements is directly or indirectly applied to most stock assessment models (Borges, 2001). Therefore updated information on MLW of commercial species has become very important (Navarro et al., 2012; Cengiz et al., 2019). Despite it's commercial importance and invasive character, no regulative tool has been applied on the fishery of S. rivulatus in Turkey.

This study presents the maximum size record of S. rivulatus for Aegean Sea with some additional biological information and the paper is considered to make a contribution to fisheries biology.

\section{MATERIALS AND METHODS}

The specimen was captured on 29 January 2018 in Gökova Bay, Southern Aegean Sea. Gökova Bay is located in the connection zone of the Aegean Sea and the Mediterranean which has been declared as "special environmental protection area -SEPA" in 1988 on account of its natural, historical and cultural significance. (GDPNA, 2014). The Maximum length sample 
was collected by trammel net by a fisherman thus ethic committee approval was not required for the study. The biggest individual of S. rivulatus was caught off Akbük Bight $\left(37^{\circ} 01.851^{\prime} \mathrm{N}\right.$, $\left.028^{\circ} 08.669^{\prime} \mathrm{E}\right)$ (Gökova Bay) (Figure 1) at $15 \mathrm{~m}$ depth with trammel nets. The Total length of the specimen was subsequently measured to the nearest $\mathrm{mm}$ and weighted to the nearest $\mathrm{g}$, where total length is expressed as the projection length between the front end of the fish head and the end point of the longest ray of the caudal fin when the mouth is closed in commercial fishery regulations of Turkey (communique no: 2016/35). Age estimation was based on otolith examination and supported with scale readings. Sagittal otoliths were removed and prepared for age readings by profiling, rubbing, and polishing. They were embedded in polyester molds and sections were obtained by cuting the mold with an IsoMet Low Speed Saw. Then, otoliths sections were polished with sandpaper (types 400, 800, and 1200) and with 3,1, and 1/4 $\mu$ particulate alumina respectively (Metin \& Kınacıgil, 2001). Age determination was carried out by a stereoscopic microscope under reflected light against a black background. Opaque and transparent rings were counted: 1 opaque zone, together with 1 transparent zone, was considered as the annual growth indicator.

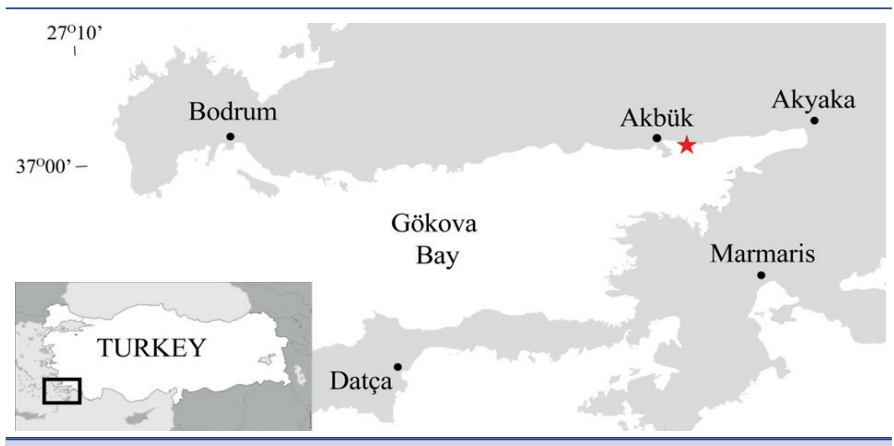

Figure 1. Sampling location of the maximum size Siganus rivulatus from Gökova Bay, southern Aegean Sea.

\section{RESULTS AND DISCUSSION}

The Captured individual of marbled spinefoot was $27.1 \mathrm{~cm}$ in total length (TL) and $414.8 \mathrm{~g}$ in total weight (TW) (Figure. 2). Some morphometric characters for S. rivulatus are given in Table 1. Sex of the specimen was female with a gonad weight of $2.43 \mathrm{~g}$. Age of the specimen was determined to be 9 years (Figure 3). The number of scientific studies with regard to the biology and other aspects of S. rivulatus are unfortunately low in Turkey due to poor scientific interest in this species and difficulties during sampling. Therefore, length and weight records for $S$. rivulatus were given for all possible localities from Turkey instead of only from the Aegean Sea, in order to make a better comparison (Table 2).

Although our TL value is the highest for Aegean Sea among the reported studies so far, it was seen that, the maximum length record of the species for Turkish waters belonged to Ergenler, (2016) with a TL value of $29.5 \mathrm{~cm}$. Even so, our individual weight measurement $(414.8 \mathrm{~g})$ is the highest value not only for Turkey but also for European waters. Discrepancies in weight measure- ments between two studies are attributable to sampling season which resulted in too much fat accumulation in our sample (Figure 2) to be used during the upcoming spawning season and stomach fullness.

The concept of maximum length is generally linked to overfishing. Individuals which are exposed to high fishing pressure will respond by reproducing at smaller sizes. This mechanism results in reducing the maximum size of the species. Furthermore, feeding habits of the species, prey-predator relationships and parameters such as nutrient availability, oxygen, salinity, temperature and pollution have serious effects on growth (Helfman et al.,

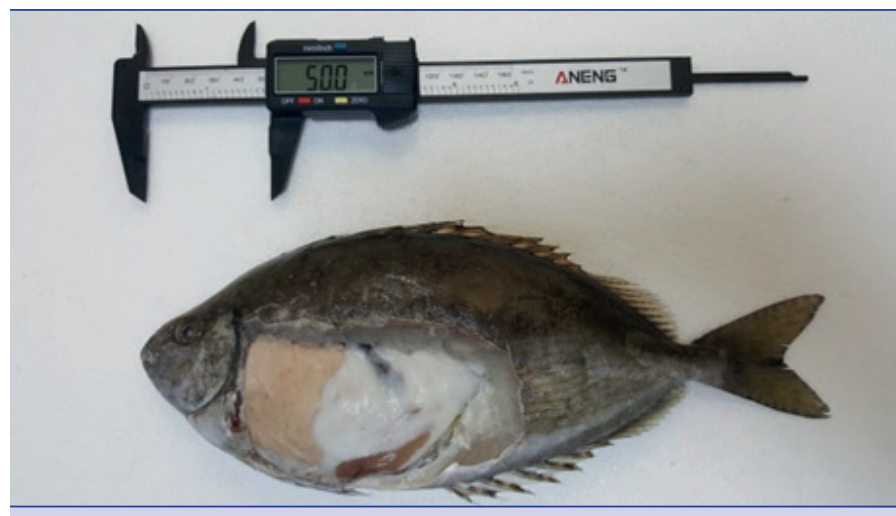

Figure 2. The maximum sized Siganus rivulatus and fat accumulation.

Table 1. Some morphometric characters for Siganus rivulatus captured from Gökova Bay, Southern Aegean Sea.

\begin{tabular}{lc}
\hline Morphometric characters & Value \\
\hline Total length $(\mathrm{cm})$ & 27.1 \\
Total weight $(\mathrm{g})$ & 414.8 \\
Standard length $(\mathrm{cm})$ & 21.9 \\
Fork length $(\mathrm{cm})$ & 25.2 \\
Max. body depth $(\mathrm{cm})$ & 9.5 \\
Girth (cm) & 22.7 \\
Head length (cm) & 4.7 \\
Preorbital length (cm) & 1.8 \\
Eye diameter (cm) & 1.4 \\
Predorsal lenght (cm) & 4.9 \\
Preanal length (cm) & 11.9 \\
Prepelvic lenght (cm) & 6.4 \\
Prepectoral fin length (cm) & 4.8 \\
Caudal peduncle minimal depth & 1.2 \\
Interorbital width & 1.5 \\
1. Length of Dorsal fin basis (cm) & 13.2 \\
2. Length of Dorsal fin basis (cm) & 4.3 \\
Total Dorsal Length & 17.1 \\
Length of anal fin basis & 9.6 \\
Gonad W (g) & 2.4 \\
Liver W (g) & 16.8 \\
\hline
\end{tabular}


Table 2. Reported maximum length and weight of Siganus rivulatus in Turkish waters in previous studies.

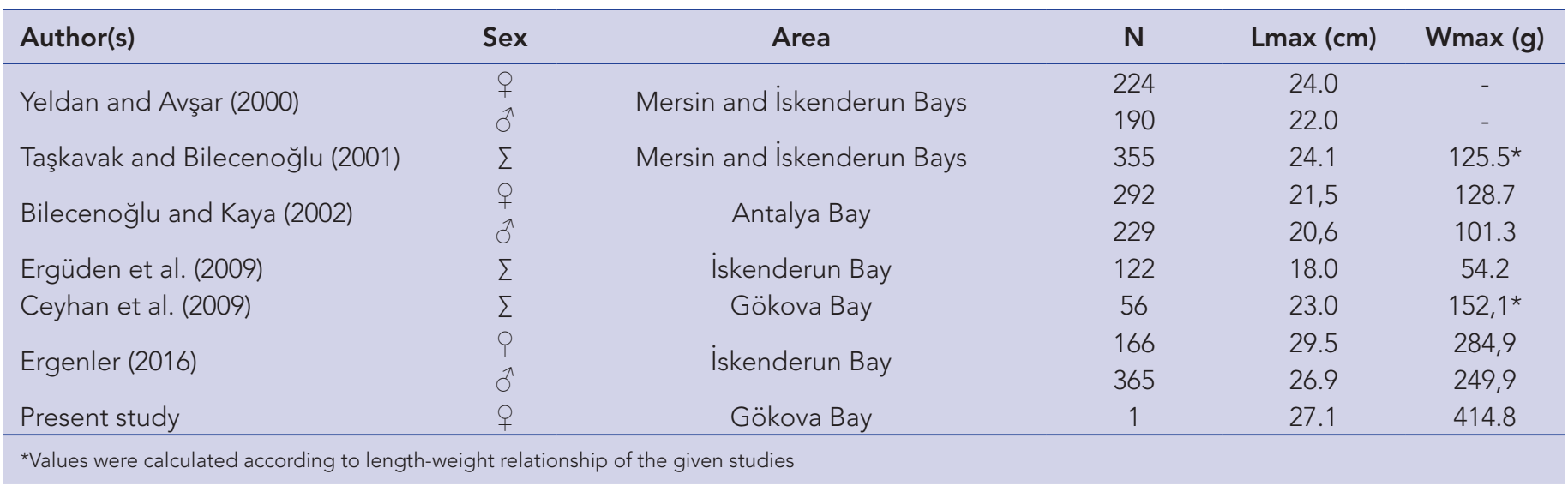

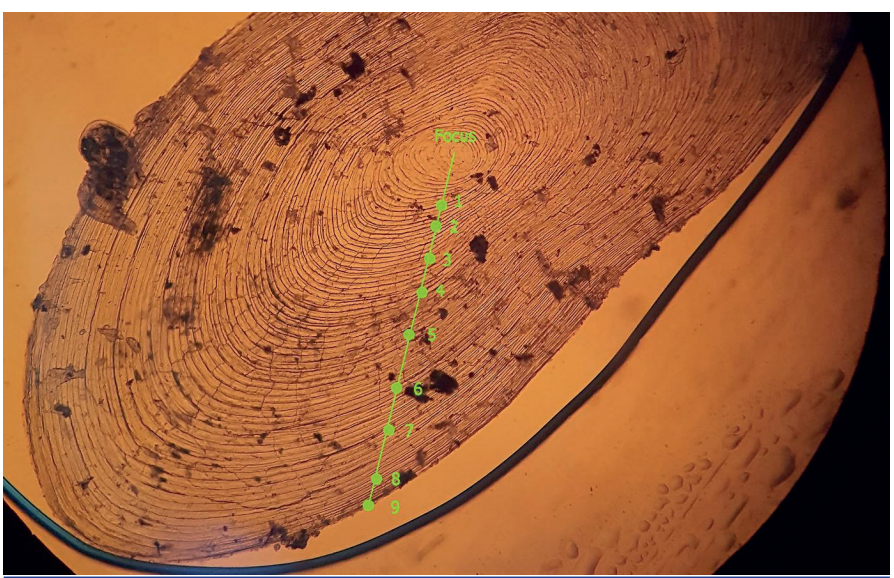

Figure 3. Age reading of the captured individual.

2009). Therefore, regional discrepancies in maximum length and weight values can be attributed to level of fishing pressure and environmental factors.

\section{CONCLUSION}

Consequently, the present study proves that this species can grow above the previously reported maximum length values in the Aegean Sea and presents the maximum weight record for Turkish waters. The information presented here is considered to make a contribution to fisheries biology and international scientific literature.

Conflict of interests: The authors have no conflicts of interest to declare.

Ethics committee approval: This study was conducted in accordance with ethics committee procedures of animal experiments.

Funding: This study was supported by Ege University Scientific Research Projects Coordination Unit. Project Number: 2016/ SÜF/014.

\section{Acknowledgments: -}

\section{Disclosure: -}

\section{REFERENCES}

Ben-Tuvia, A. (1985). The impact of the Lessepsian (Suez Canal) fish migration on the eastern Mediterranean ecosystem. In M. MoraitouApostolopoulou \& V. Kiortsis (Eds.), Mediterranean Marine Ecosystems (pp 367-375). New York: Plenum Press. [CrossRef]

Bilecenoğlu, M. \& Kaya, M. (2002). Growth of marbled spinefoot, Siganus rivulatus, (Forsskål, 1775, Teleostei: Siganidae) introduced to Antalya Bay, eastern Mediterranean Sea (Turkey). Journal of the Fisheries Research, 54(2), 279-285. [CrossRef]

Borges, L. (2001). A new maximum length for the Snipefish Macrohamphosus scolopax. Cybium, 25, 191-192.

Cengiz, Ö. (2019). Weight-length relationships with maximum length record of striped sea bream (Lithognathus mormyrus Linnaeus, 1758) for Turkish Seas (in Turkish with English abstract). Yüzüncü yıl Üniversitesi Tarım Bilimleri Dergisi, 29(3), 382-387. [CrossRef]

Ceyhan, T., Akyol, O. \& Erdem, M. (2009). Length-Weight Relationships of Fishes from Gökova Bay, Turkey (Aegean Sea). Turkish Journal of Zoology, 33, 69-72.

Dulčić, J., \& Soldo, A. (2005). A new maximum length for the grey triggerfish, Balistes capriscus Gmelin, 1789 (Pisces: Balistidae) from the Adriatic Sea. Institute of Oceanography and Fisheries-Split Croatia, 88, 1-7

Ergenler, A. (2016). The Investigation Some Biological Characteristics Marbled Spinefoot (Siganus rivulatus Forsskal, 1775) Living in Iskenderun Bay. M.Sc. Thesis. İskenderun Teknik Üniversitesi Mühendislik ve Fen Bilimleri Enstitüsü, 53 pp.

Ergüden, D., Turan, C. \& Gürlek, M. (2009). Weight-length relationships for 20 Lessepsian fish species caught by bottom trawl on the coast of Iskenderun Bay (NE Mediterranean Sea, Turkey). Journal of Applied Ichthyology, 25, 133-135. [CrossRef]

Froese, F. \& Pauly, D. (2019). Fish Identification, Family: Siganidae, Rabbitfishes. From, http://www.fishbase.org/summary/Siganusrivulatus.html (accessed 12.02.2019).

GDPNA (General Directorate for Protection of Natural Assets). (2014). Fethiye-Göcek, Köyceğiz Dalyan, Datça-Bozburun, Gökova, Foça Special Environment Protection Areas and Ayvalık Adaları Nature Guide Book, PIMS 3697: The Strenghtening the System of marine and Coastal Protected Areas of Turkey Project, 64, (in Turkish).

Helfman, G. S., Collatte, B. B., Facey, D. E. \& Bowen, B. W. (2009). The diversity of fishes: biology, evolution and ecology. UK: Wiley-Blackwell.

Metin, G. \& Kınacıgil, H. T. (2001). The sectioning technique in age determination by otolith. Ege Journal of Fisheries and Aquatic Sciences, 18, 271-277.

Navarro, M. R., Villamor, B., Myklevoll, S., Gil, J., Abaunza, P. \& Canoura, J. (2012). Maximum size of Atlantic mackerel (Scomber scombrus) and Atlantic chub mackerel (Scomber colias) in the Northeast Atlantic. Cybium 36, 406-408. 
Saoud, I. P. \& Ghanawi, J. (2010). Culture potential for Marbled Spinefoot Rabbitfish (Siganus rivulatus). The Practical: Asian Aquaculture, 1(1), 15-17.

Taşkavak, E. \& Bilecenoğlu, M. (2001). Length-weight relationships for 18 lessepsian (Red Sea) immigrant fish species from the eastern
Mediterranean coast of Turkey. Journal of Marine Biological Association of the United Kingdom, 81, 895-896. [CrossRef]

Yeldan, H. \& Avşar, D. (2000). A Preliminary study on the reproduction of the Rabbit fish (Siganus rivulatus Forsskal, 1775) in the Northeastern Mediterranean. Turkish Journal of Zoology, 24(2), 173-182. 